MH Egészségügyi Központ Védelem-egészségügyi Igazgatóság

Tudományos Könyvtár

\title{
A „Honvédkórház” a Ludoviceum épületében
}

\author{
Pogányné Dr. Rózsa Gabriella PhD
}

Kulcsszavak: katona-egészségügy története, Honvédkórház XIX. század

\begin{abstract}
Az 1781-ben alapított Honvédkórház 1849-ben költözött az Invalidusok Palotájából a Ludoviceum épületébe és itt müködött 1871-ig. Az Orczy-kertben álló épületet eredetileg a magyar katonai iskola céljaira emelték, de csak a kiegyezés és a Magyar Honvédség megszervezése után nyílhatott meg az intézmény. A tanulmány korabeli levéltári és nyomtatott források felhasználásával mutatja be a kórház ezen korszakának történetét.
\end{abstract}

A Habsburg Monarchia Mária Teréziának köszönhette felsőfokú katonai szakképzését, és a királynő az általa alapított számos intézmény közül kedvencének tekintette és gyakran meglátogatta az 1752-ben Bécsújhelyt (Wiener Neustadt városában) életre hívott Theresianische Militärakademie-t [1], amelyet a mai jogutód a világ legrégebbi katonai akadémiájaként hirdet [2]. Mindazonáltal a Birodalom magyar alattvalói, magyar katonatisztjei már a XVIII. században sem voltak elégedettek e patinás iskolával, hiszen ebben is a nemzeti törekvések, identitás és nyelvhasználat akadályát látták. Az 1790-es években több beadvány született, amely a magyar ezredek számára magyarnyelvüséget követelt, és hamarosan az önálló nemzeti tisztképzés megteremtésének szükséges volta is kinyilváníttatott. Végül az 1808-as pozsonyi országgyülés mondta ki a magyar kato- nai szakképzés intézménye, a Ludovika Akadémia vagy ahogyan sokszor emlegették, a Ludoviceum megalapítását [3].

Az oktatás azonban csak jóval később indulhatott meg a tiszti iskola számára az Orczy-kertben 1836-ban emelt épületben [4], jelen dolgozat szempontjából legfontosabb „gátló tényezö" ebben a pesti katonai kórház, a Honvédkórház korai jogelődjének beköltöztetése volt az ingatlanba.

A mai Honvédkórház hosszú története 1781-ben indult [5], ekkor alapította II. József a pesti katonai kórházat, amely eleinte a volt jezsuita kollégiumban müködött. Az épület ma már nincs meg, helye a Kossuth Lajos utca és a Semmelweis utca találkozásánál van. Innen 1783-ban költözött az Invalidusok Palotájába, ahol egészen az 1848/1849-es forradalom és szabadságharc végéig szolgálta a sebesült vagy beteg katonákat. 
A korabeli kiadványok érdekes adalékokkal szolgálnak az ,ispotály” működésével kapcsolatban. Budapest történetének nagy tragédiája volt az 1838-as árvíz, az ennek eseményeiről beszámoló korabeli „ponyva-kiadvány” szerint sokfelé hallatszott, hogy az ár házakat sodort el, ezért sokan nem mertek hazamenni, hanem a város nagy épületeiben kerestek menedéket, például a templomokban vagy a kaszárnyákban, és maga az Invalidusok háza, valamint a Neugebäude, illetve számos foúri palota is megtelt emberekkel. (A kiadvány arról úgyszintén beszámolt, hogy a császári sereg tábori sütödék telepítésével is mentette a lakosságot [6]). Másik forrás szerint „A' lak nélkül maradtak nagyobb tömegekben a’ Ludoviceum, sz. Ferencziek épülete, invalidház, újépület, $\mathrm{k}$. kúria, 's lövészháznál tápláltatnak; a' betegek számára is rendelések tétettek, mi végre az úgynevezett tábori kórház [a mai Soroksári úton] most készittetik el" [7].

Az 1808-ban, illetve újabb kiadásban 1815-ben közzétett katona-egészségügyi szabályok szerint a pesti katonai kórház helyőrségi (fö)kórházi rangot kapott, így joggal említődik a Schlesinger Ignác orvos által jegyzett korabeli összefoglaló munkában, a Medicinische Topographie der königlichen Freistätte Pesth und Ofen [8] című opuszban is „GarnisonsSpital"-ként az intézmény. Az 1840-ben publikált leírás szerint „a pesti helyőrségi kórház ... a szép invaliduspalota keleti felében található", és 14 kórteremben mintegy háromszáz beteg ápolására alkalmas, de szükség esetén a betegek száma a „dicséretes” tisztaság veszélyeztetése nélkül négyszáz före is emelhető. (Érdemes megjegyezni, hogy a költözéskor a kórházat 250 före tervezték, de a korai időszakban volt, amikor 600 betege is volt egyidejüleg [9]). A Schlesinger kötetében közölt betegforgalmi statisztikai adatok szerint az ott kezeltek száma 4686 fö, a gyógyultaké 3795 és a megholtaké 401, 490 föt pedig más katonaegészségügyi intézménybe szállítottak át. A kórház irányítása egy törzsorvos kezében van, munkatársai ezredorvosok, akik két-két hónapot szolgálnak az intézmény falai között. Az emeleten a sebesültek vannak elhelyezve, a földszinten pedig a betegek, akik közül a szifiliszben szenvedők alkotják a legnagyobb „osztályt”. Két kisebb helyiség áll a katona-feleségek rendelkezésére, de a szerző sérelmezi, hogy őket is férfi ápolók gondozzák. A kórház felszerelése megfelel az akkor a katonai kórházaktól a Biroda-

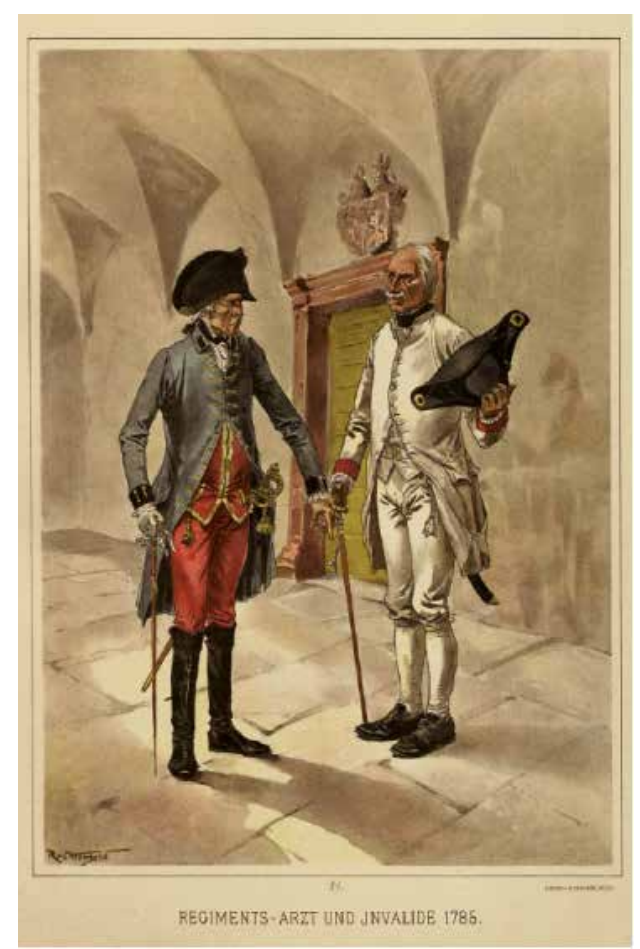

1. ábra. Ezredorvos és invalidus 1786

(Teubner, O.: Die Österreichische Armee: von 1700 bis 1867. [Tafelband].

Ill. Rudolf von Ottenfeld. Wien, [1904], Verlag von Emil Berté \& $C^{i e}$ und Czeiger. [81].) 


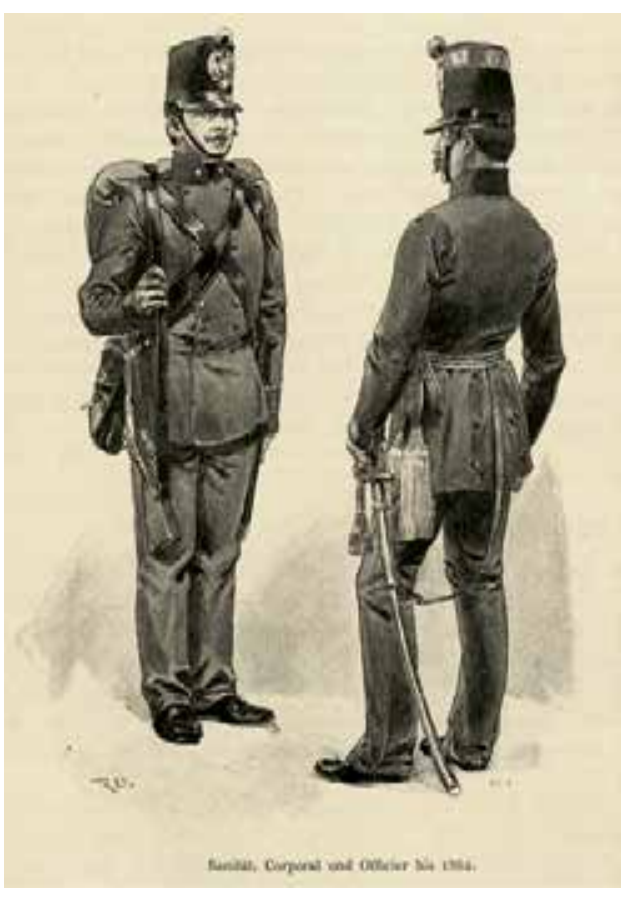

2. ábra. Szanitéc (egészségügyi) tizedes és tiszt 1862-ig (Teubner, O.: Die Österreichische Armee : von 1700 bis 1867. [Textband]. Ill. Rudolf von Ottenfeld. Wien, 1893, Verlag von Emil Berté \& C $C^{i e}$ und Czeiger. 670.)

lomban elvártaknak, de elhelyezése nem szerencsés egyrészt a kert hiánya miatt, másrészt pedig azért, mert a gyógyító munka nem tud elég hatékony lenni a sürün lakott, szük utcás környezetben. És Schlesinger müve már utal arra a későbbi tervre, hogy a lipótvárosi 5 . tüzérezred laktanyájába, az 1848-1849-es forradalom és szabadságharc után hirhedtté vált Neugebäudéba költöztessék a kórházat. (Az Ujépület kórházi hasznosítása végül be is következett, a Hadtörténelmi Levéltárban fellelhető iratok szerint 1852-ben az ingatlan a pesti helyörségi főkórház 4. Filial-Spitaljaként említődik, Buda, Óbuda [10] és a kecskeméti alakulatok ispotálya [11] mellett. Dr. Franz Petter törzsorvos, a pesti helyőrsé- gi fókórház akkori vezető orvosa pedig 1853. szeptember 15-én kelt és a harmadik hadtestparancsnokságnak címzett levelében a kecskeméti katonai lovarda épületében átmenetileg elhelyezett 80 beteg hadfi számára a téli hónapok közeledtével megfelelő ellátásáról akart gondoskodni, ezért 400 beteg gyógyítására plusz férőhelyek megteremtését javasolta a Neugebäudeban müködő fiókkórházban. Ugyanezen év októberében az Új Épületben tábori patika felállításáról is gondoskodott Petter doktor [12]). A Medicinische Topographie szerzője a kórházat összességében példaértékünek bemutató leírása azonban ottani látogatása során tapasztalt néhány problémára szintén felhívja a figyelmet. Egyrészt a galériás helyiségekben magasan lévő betegek gyógyulására károsan hat az alulról jövők „kipárolgás”-a, másrészt a szembetegek részére az erős fénytől való védelem nagyobb mérvü biztosítását javasolja.

1849-ben azonban a kórház elhagyva az invalidusok palotáját, hatalmi szóra - a bécsi Fremden-Blatt szóhasználatával: „katona-egészségügyi szempontok figyelembevételével" - a Ludoviceum épületébe, illetve a Valero-féle selyemgyár lipótvárosi ingatlanjába költözött [13]. (Utóbbival kapcsolatban A Honvéd 1871. június 29-ei számában arról lehet olvasni, hogy a gyártelepet 1848-ban a magyar kormány megvásárolta tulajdonosától, majd „1849-ben a nemzettől erőszakkal elvétetett, kaszárnyává alakíttatott át és még a mai napig is a katonai kincstár körme közt van”. A cikk szerzője szerint „ez a gyár a magyar nemzet elvitathatatlan tulajdona", tehát, ha már laktanyaként müködik, akkor a magyar Honvédséget kellene szolgálnia [14]).

Így a Ludovika Akadémián az oktatás annak ellenére, hogy az 1848/1849- 
es forradalom és szabadságharc törekvései és szükségletei között a magyar nyelvü és érzelmű tisztképzés megindítása szintén szerepelt, mégis újabb halasztást szenvedett. 1848. május 29-én Mészáros Lázár hadügyminiszter intézkedett a megnyitás előkészítésére, és július 22-én az országgyülés megtárgyalta a Magyar Katonai Főtanoda tervezetét [15]. Ekkoriban a sajtó szintúgy foglalkozott e kérdéssel: „Hogy tehát újjá született nemzetünk jövendőre is bár melly ellenséggel szembeszállhasson, nem kellene késni, sőt hovahamarább egy katona fö-képezdét is, - ott áll már a roppant Ludoviceum - életbeléptetni, s ebben 12-16 évekig alkalmatos legalább 300 ifjat $s$ pedig a gyengébbeket az elemiekben, az idősbbeket a legszükségesb hadtudományokban s rendszeres lovaglásban kimüveltetni." [16] - olvasható a Budapesti Híradóban. A Márczius Tizenötödike újságírója pedig a következöképpen vélekedik: „Végre még egy mély sóhajtás hozzád oh! Ludoviceum! Mikor vi[r]rad már fel valahára honunk egész neved alatt elrejtett sok bün, kár, és hibák után dicső feltámadásod hajnala? mikor fogod már el láthatni drága falaidba kiképezett valódi magyar honfi tisztekkel ezredeinket? Polgár ministerek! az árván álló Ludoviecum hazánk lehető nagy neve és hírének egyik reményfoka! Lássatok hozzá erőteljesen! - annak életbe léptetése által halhatatlanokká fogjátok tenni neveiteket az utókor előtt." [17]

1849. január 7-én meg is tartották a Ludovika Akadémia első tanévének megnyitását, de „a következő napokban a Ludoviceum igen látogatott volt. Osztrák tábornokok és törzstisztek sürün fordultak meg az intézetben, melynek berendezése nagyon megtetszett nekik és nyíltan ki is mondták, hogy a Ludoviceum továbbra is fenn fog ma- radni. ... Január 16-án két század horvát gyalogság vonult az intézet elé. Az épületek kapuinak megszállása után egy tiszt betért az udvarba és meghagyta, hogy a tanárok azonnal jöjjenek le. Ez megtörténvén felolvasta nekik a parancsot, hogy aznap este 9 óráig az intézetből mindenki kitakarodjék." [18], ezután január 17én Windischgrätz ingóságaival együtt lefoglalta az épületet és katonai kórházat telepített bele [19].

A Ludoviceum Pest 1849. április 24ei visszafoglalása után gyakorlatilag a honvédsereg kórházaként működött, és annak ellenére, hogy júniusban felvetödött az iskola kiürítése és eredeti funkciója számára visszaadása, Lumnitzer Sándor hadügyminisztériumi egészségügyi osztályfőnök (osztályvezető) javaslatát fogadták el, így az intézmény a honvédsereg központi tábori kórháza [20], majd a szabadságharc bukása után a császári sereg ispotálya maradt. A Wiener Zeitung 1850. március 9-én úgy tudta, hogy a pesti helyőrségi fökórház nemsokára a Károly kaszárnyából, vagyis az Invalidusok házából a Ludovika épületébe fog költözni [21]. Egy 1850. november 29-ei jelentés szerint a katonai kincstár az épületet 1 . számú tábori fökórháznak, az 5. sz. tüzérezred tábori kórházának és fö helyőrségi kórháznak használja [22].

A Pressburger Zeitung hírei között lehet rábukkanni arra, hogy 1850. május 12-én „Noszlopi [Noszlopy Gáspár], a hírhedt gerillavezér, akit 14 napja fogtak el a bakonyi erdőkben, megszökött a Ludoviceumban működő kórházból. Noszlopi nyolc nappal korábban betegnek tettette magát, ... vele együtt szökött az egyik szanitéc, aki korábban a honvéd seregben szolgált" [23].

A Habsburg Birodalom helyőrségi kórházi hálózatát az 1850. december 9-én kelt és báró Anton Csorich 
von Monte Creto által jegyzett 6784es számú hadügyminiszteri rendelet [24] kibővítette és újjászervezte. Az immáron Bécs, Komárom, Eger és Pest mellett Graz, Innsbruck, Prága, Ollmütz, Theresienstadt (Terezín), Milánó, Verona, Mantua, Velence (fiókkórháza Padova), Trieszt, Temesvár, Pétervárad, Kolozsvár, Lemberg és Krakkó helyőrségeiben müködő Garnison-Spital-ok három területre kiterjedő komplex funkciórendszert láttak el. Céljuk egyrészt a nagyobb csapattestek tehermentesítése saját kórház fenntartása és müködtetése alól, valamint a rendelet kifejezésével élve „példamutatás”, mai szóval élve módszertani segítségnyújtás az adott örökös tartomány alakulatai által müködtetett katonai kórházak számára, illetve a részvétel a katonai szolgálatba lépő civil orvosok és sebészek, a katonai-egészségügyi szakszemélyzet, illetve a kórházak gazdasági, logisztikai személyi állományának képzésében. Ezen feladatcsoport keretén belül a gyakorlóhely biztosítása mellett az elméleti katona-egészségügyi kiképzés, a vonatkozó szabályzatok, előírások oktatása úgyszintén rájuk hárult. A helyörségi kórházi rangból következő harmadik felelösségi kör „szükséghelyzet"-ben, mozgósítás idején a tábori kórházak, illetve kórházi hálózat mielőbbi megszervezése. (Saját szakmámhoz „hazabeszélve" ki kell emelnem, hogy ezen "Cirkular-Verordnung” óta kell a helyőrségi kórházaknak orvosi szakkönyvtárral rendelkezniük, melynek megalapítására, illetve éves gyarapítására Csorich hadügyminiszter rendelete pénzügyi forrásokat is rendelt, fix kereteket határozott meg.)

Mindazonáltal a helyőrségi kórházi müködés mellett még továbbra is megmaradtak az épület korábbi életének rekvizitumai, 1851 tavaszán „fel- sőbb rendelet következtében megszüntetett Ludoviceum bútorait e napokban a muzeum terén árverés utján adatta el a hatóság. Ágynemüek, öltönyök, edények, házi eszközök stb. nagymennyiségben adattak el. E darabok közt nem egy volt, mely a régótai heverés miatt csak nem egészen megromlott. Mindazáltal meglehetős áron keltek. Nem tudni, vájjon mi czélra fogják ezután fordítani a nagyszerü épületet, mely oly szép jövővel biztatta egykor alapitóit. Jelenleg, mint tudjuk katonai kórháznak vagy laktanyának használják" [25].

A funkciót érintő bizonytalanság, illetve a hadsereg és a hatóságok közötti tulajdonvita is elhúzódott, sokáig nem volt világos az épület további hasznosításának módja (kórház, börtön vagy a császári sereg hadapródiskolája); néhány hónappal később az a hír járta, hogy a „Bécsi lapok szerint a pesti Ludoviceum tébolydává fogna átalakíttatni. Az erre vonatkozó javaslatok már vizsgálat alá terjesztettek" [26]. Végül azonban az épület kórházi célokra való alkalmazása győzött, és a Ludoviceum egészen 1871ig adott otthont a pesti helyörségi (fö) kórháznak, 1870-től használatos megnevezésével a 16. számú helyőrségi kórháznak.

A mai Honvédkórház Ludoviceumbeli életéről is találni információkat korabeli szakkönyvekben. Pest 1853-as egészségügyi adatai olvashatók Tormay Károly Medicinische Topographie der Stadt Pest címü tomusában. Ezek szerint a pesti helyőrségi kórház a kétszintes „nagyszerü Ludoviceum-épületben” található, és nagyszámú beteg ellátására alkalmas. A kórház nagy és szépen kialakított parkkal rendelkezik és itt található a jó minőségü ivóvizet adó úgynevezett Éliás-kút." Tormay értékítélete szerint „nem találni még egy ilyen intézetet 


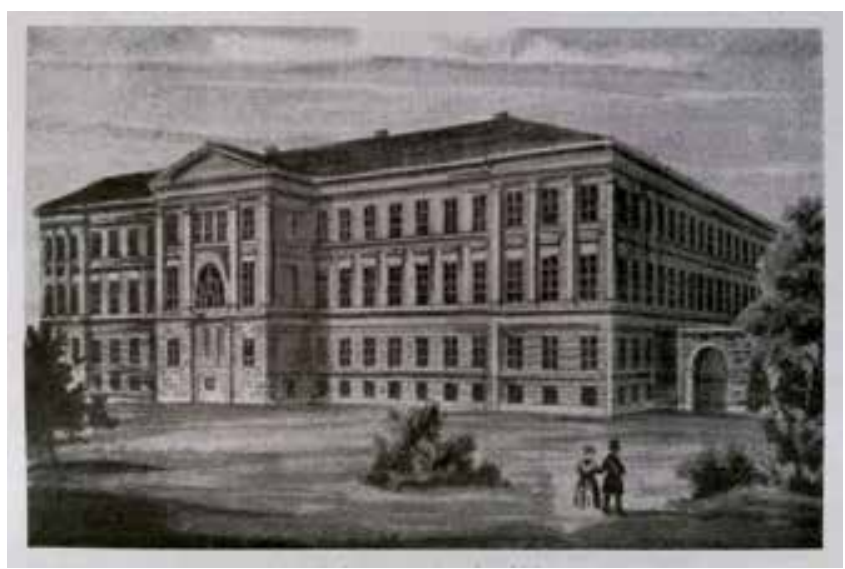

3. ábra. A Ludoviceum az Orczy-kert felól az 1850-es években (Rada T.: A Magyar Királyi Honvéd Ludovika Akadémia és a testvérintézetek összefoglalt története: (1830-1945). 1. kötet. Calgary - Budapest, 1998, Bánkuty Géza. 63.)

Európában" [27]. (A szerzőröl érdemes megjegyezni, hogy a forradalom és szabadságharc alatt a magyar kormánytól egészségügyi tanácsosi címmel tisztelték meg, a megtorlás időszakában hadbíróság elé állították, de kegyelmet kapott, utóbb Pest tisztiorvosaként tevékenykedett [28]).

Az 1856. október 2-án a kórház bejárásának, vizitációjának jegyzőkönyve szerint a „nagyszámú beteg” éppen 815 fő volt, akiket 56 kórteremben ápoltak. A betegszobák teljes kapacitása ekkor 1224 ágyat számlált; az előző felülvizsgálattól, 1855. október elejétől számított éves betegforgalom pedig 9857 beteg és 5283 sebesült, összesen 15140 fö volt. A hivatkozott jelentés elismeröen szól a kórház kertjéről, de megjegyzi azt is, hogy a további, akkor már tervezett fejlesztéshez, fásításhoz hozzáértő kertész alkalmazása szükséges. A PesthOfner Localblatt 1857. április 15-ei száma pedig arról tudósít, hogy mód nyílt az épület előtti elhanyagolt állapotú térség parkosítására, amely a kórházban lábadozók számára is kellemes pihenőhelyül fog szolgálni [29], pár héttel később a Nemzeti Múzeum termeiben megrendezett virágkiállítással kapcsolatban az is megjelent a lap hasábjain, hogy a Ludoviceum „kertművésze” Hermann Petz volt [30].

Hátrányul említették a vizitátorok a higiéniai körülmények helyenkénti hiányosságait és a várostól való nagy távolságát, a megközelítés nehézkes voltát [31], sőt az is tudható, hogy 1855-ben egészen a Mária Terézia laktanyáig egyetlen lámpa sem volt az Üllöi úton [32].

Összehasonlításként azonban érdemes egyéb forrásokból származó és más szempontú adatokat, adalékokat is figyelembe venni az 1850-es években nyilvánossá tett és Pest kedvelt kirándulóhelyeként fungáló Orczy-kert, illetve az ingatlan közvetlen környezetének állapotáról. „A megnyitást [1872] megelőzően a Ludoviceum épülete és környéke igen elhanyagolt volt. ... A nagyudvaron levő kutak vize ihatatlan volt és ivóvíznek csak a kertben levő kutak vizét lehetett használni ... Az épület átvétele idején az előtér is a legnagyobb elhanyagoltság képét mutatta. Nem lévén sem befásítva, sem bekerítve, keresztül-kasul kocsi- 
káztak és lovagoltak rajta. Itt pihentették és itatták állataikat a marhahajcsárok és kanászok, így az egész környék levegője igen kellemetlen lett. Az éjjeli világítás igen szegényes volt, ami nagyon elősegítette azt, hogy az előtér bokrai közt sok gyanús elem ütötte fel éjszakai tanyáját" [33]. A helyszín rendezésére pedig számos további terv készült és kísérlet történt, a Pesth-Ofner Localblattban már 1856-ban olvashatunk az ,igazi sétaút”ról [34]; de az még 1860 szeptemberében is csupán a jövő víziója, hogy az Üllői utat a Ludoviceum épületéig fasorrá alakítják, illetve a háztulajdonosokat arra ösztönzik, hogy a földszintes épületeket emeletráépítéssel és szép portálok kialakításával tegyék egyöntetűbbé és esztétikusabbá [35].

Az 1850 és 1871 közötti korszakban kiadott új katona-egészségügyi szabályzatok nem a helyőrségi kórházi feladatkörrel foglalkoztak, hanem a rendszer egészére vonatkozó szervezeti, szervezési kérdéseket érintették, például a helyőrségi kórházi hálózatot újabb intézményi elemekkel bővítették, sorszámmal látták el, vagy a kórházparancsnokok személyéről rendelkeztek [36]. İgy a területen bekövetkező változások közvetlenül nem befolyásolták a pesti helyőrségi kórház mindennapjait, az intézmény Ludoviceum-beli korszaka kiegyensúlyozottnak tekinthetö, a 16 . helyőrségi kórház jó színvonalon szolgálta a modernizálódó és azokban az évtizedekben több háborúban, illetve a Birodalom határain belüli fegyveres konfliktusban (1859, 1866, 1869 [37]) bevetett hadsereget.

Mindamellett néhány további érdekes adalékkal is szolgál a korabeli sajtó a kórházzal kapcsolatban. A rendelkezésemre álló források alapján 1852. június 7-én volt az első uralkodói látogatás a Ludovi- kában működő katonai kórházban [38], 1857-től pedig több alkalommal részesültek az itt ápolt katonák ezen császári és császárnéi kegyben. „Császár Ő Felsége ... több katonai telepet szemlélt meg, névszerint a nagy katonai kórházat a Ludoviceumban, a betegeknek szintúgy a legmagasb megjelenés által a szenvedők ágyánál, mint majd minden egyesnek jóakaratúlag kifejezett és kegyteljes részvét által vigaszt és enyhülést szerezvén" [39]. A Der Vaterland szerint 1865. december 18-ára is tervben volt az uralkodó vizitje a helyőrségi kórházban [40], 1866. július 10-én pedig Erzsébet királynő járt a Ludoviceumban ápolt sebesülteknél és „ágytól ágyhoz lépve bíztató szavakkal vigasztalta a katonákat" [41].

Közben azonban maga a gyógyintézmény, de a Birodalom katonaorvoslása is jelentős orvostechnikai fejlödést ért meg, „dr. Weiger József első cs. k. had-orvos módszere a kénégenynyeli (éteres [42]) bódítás használásában czélszerünek bizonyult be..., 1847. óta $d r$. Weiger mintegy 60,000 [!] mütétet végzett bódítás segélyével $\mathrm{s}$ mind a legjobb sikerrel." A módszer 1854-ben rendszeresíttetett az osztrák hadseregben, így a pesti helyőrségi fökórházban is [43]. 1856-tól gőzmosoda és fürdő szolgálta a beteg katonák gyógyulását [44], 1855. május 29-én pedig a kórházparancsnok pályázatot írt ki az épületben egy nagy, két haranggal működő házi óra készíttetése tárgyában [45].

A kiegyezés után teremtődött meg a magyar nemzeti hadsereg létrejöttének jogi alapja, és nem sokkal a Honvédség megalapítása után a régóta vágyott magyar katonai akadémia megszervezése is megkezdődött. Az iskola helyszínéül pedig a Kincstár a Ludoviceum épületét és a hozzá tartozó Orczy-parkot nevezte meg [46], így végre napirendre került 
a helyőrségi főkórház kiköltöztetése az ingatlanból. A Főváros és a Honvédelmi Minisztérium megállapodása szerint az Üllői út külső részén, a vámon túl kapott telket a császári sereg a felállítandó katonai „baraquekórház” részére 10 éves átmeneti időre [47]. A 16. helyőrségi kórház végül a 1871-ben kezdte meg barakk-kórházi működését új telephelyén, a Ludovika pedig 1872-ben nyitotta meg kapuit az eredetileg is ezen célra szánt régi-új épületében.

\section{Irodalom}

[1] Lang, C.: Maria Theresia : Vortrag gehalten im Militar-wissenschaftlichen Vereine zu Lemberg am 11. März 1887 ... Streffleur's Österreichische Militärische Zeitschrift. 1888. 2. 9.

[2] Theresianische Militärakademie. Die Militärakademie besuchen. https://www.milak.at/ besucherinformation/die-militaerakademiebesuchen

[3] Vö. Rada T: A Magyar Királyi Honvéd Ludovika Akadémia és a testvérintézetek öszszefoglalt története : (1830-1945). 1. kötet. Calgary - Budapest, 1998, Bánkuty Géza. 24-28.

[4] Siposné Kecskeméthy K. - B. Kalavszky Gy.: A Ludovika egykor és most. 2., jav., bőv. kiad. Budapest, 2018, Zrínyi. 2018. 19.

[5] Részletesebben és újabban vö. Pogányné Rózsa G.: A Honvédkórház 120 éve. Budapest, 2019, Zrínyi. 9-10.

[6] Beschreibung einer fürchterlichen Ueberschwemmung im Monate März 1838... Raab in Ungarn, [1838], Streubig. [3].

[7] Buda-pesti áradás. Alveare = Méhkas. 1838. 89.

[8] Schlesinger I.: Medicinische Topographie der königlichen Freistätte Pesth und Ofen. Pesth, 1840, Kilian. 158.

[9] Takáts L.: Hazai források a katonakórházak 17-18. századbeli fejlődéséhez. 2. rész. Honvédorvos. 1976. 260.
[10] HM HIM Hadtörténelmi Levéltár [a továbbiakban: HL] HL. I. 2. III. Armee Commando. 1853. Präs. (1-76.). 1830. doboz. 30., 35. 40., 60., 68. iratok.

[11] HL. I. 2. III. Armee Commando, Reserve Truppen Commando. 1854. III. 2. 1867. doboz. 22/56. irat. Musterungsplan. Pest, 1854. augusztus 31 .

[12] HL. I. 2. III. Armee und Landes General Commando. 1853. III/5. (23-48.) 1829. doboz. 38/6., 44/2., 46/1. iratok.

[13] Fremden-Blatt. 30 Januar 1850. 1.

[14] A budai urak és a Valero-gyár. A Honvéd. 1871. június 29. 403.

[15] Rada T.: A Magyar Királyi Honvéd Ludovika Akadémia és a testvérintézetek összefoglalt története : (1830-1945). 1. kötet. Calgary - Budapest, 1998, Bánkuty Géza. 56.

[16] Honvédelmi erő. Budapesti Híradó. 1848. május 23. 490.

[17] A. E.: Egy szó... Márczius Tizenötödike. 1848. május 31. 266.

[18] Rada T.: A Magyar Királyi Honvéd Ludovika Akadémia és a testvérintézetek összefoglalt története: (1830-1945). 1. kötet. Calgary - Budapest, 1998, Bánkuty Géza. 59.

[19] Siposné Kecskeméthy K. - B. Kalavszky Gy.: A Ludovika egykor és most. Budapest, Zrínyi, 2018. p. 20.

[20] Vö. Ács T.: A Magyar Hadi Főtanoda, 18481849. Hadtörténelmi Közlemények. 1999. 333.; 337-338.; Ács T.: A magyar katonai akadémia elötörténete : A tervtől a megnyitásig (1790-1849). Hadtörténelmi Közlemények. 2013. 98.

[21] Kronländer. Wiener Zeitung. 9. März 1850. 739.

[22] HL MDC. 1850: 172:11855 hivatkozza: Sági E.: A pesti császári és királyi helyőrségi kórház története az alapítástól a szabadságharc utáni évekig. Orvosi Hetilap. 2011. 958.

[23] So eben verlautet. Pressburger Zeitung. 17. Mai 1850. 498.

[24] Vö. Circular-Verordnung des Kriegsministers v. 9. Dec. 1850. D. 6784. Vierteljahrsschrift für die praktische Heilkunde. 1851. 3. Hauptteil. $34-42$. 
[25] Pesti Napló. 1851. március 17. [3].

[26] Bécsi lapok szerint. Gazdasági Lapok. 1851. augusztus 3. col. 730 .

[27] Tormay K.: Medicinische Topographie der Stadt Pest ... des Jahres 1853. Pest, 1854, Eggenberger. 4., 10., 100.

[28] Részletesebben vö. Tamáska P.: Tormay Károly jelentése Pest közegészségügyének 1852. évi helyzetéről. Orvostörténelmi Közlemények. 105-106. Budapest, 1984, Semmelweis Orvostörténeti Múzeum, Könyvtár és Levéltár - MOTESZ Magyar Orvostörténeti Társaság. 117-128.

[29] Pesth-Ofner Localblatt. 15. April 1857. 1.

[30] Pesth-Ofner Localblatt. 9. Mail 1857. 3.

[31] HL. I. 2. III. Armee und Landes General Commando. III/5. (21-24.) 2180. doboz. 21/7. irat.

[32] Bachó L.: Adalékok a Ludovika Akadémia történetéhez. Ludovikás Levente. 1935. 71.

[33] Rada T.: A Magyar Királyi Honvéd Ludovika Akadémia és a testvérintézetek összefoglalt története : (1830-1945). 1. kötet. Calgary

- Budapest, 1998, Bánkuty Géza. 64.

[34] Pesth-Ofner Localblatt. 8. Februar 1856. [1].

[35] Die Pesther Alleeschlange. Pesth-Ofner Localblatt. 6. September 1860. [3].

[36] Vö. Kirchenberger, S.: Geschichte des k. und. k. österreichisch-ungarischen MilitärSanitätswesens. Wien, 1895, Šafář. 154-161.

[37] Részletesen vö. Magyarország hadtörténete / szerk. Hermann R. 3. kötet, Magyarország a Habsburg Monarchiában : 1718-1919. Budapest, cop. 2015, Zrínyi, 191-208., 247-248.

[38] Preojektiere Zeiteintheilung ... Wiener Zeitung. 4. Juni 1852. 1550.; a beszámolót ld. Oesterreich. Aufenthalt Sr. k. k. Apostolischen Majestät in Ungarn. Wiener Zeitung. 11. Juli 1852. 1907.

[39] Pesti Napló. 1857. május 10. [2]; ugyanez: Pesth-Ofner Localblatt und Landbote. 1857. május 10. [2].
[40] Der Vaterland. 17. Dezember 1865. 2.

[41] Pest, 10. Juli. Das Vaterland. Abendblatt. 11. Juli 1866. 2.

[42] Vegytanszótár. In: A legjobbnak tapasztalt házi szerekről. URL: https://sites.google. com/site/legjobbszerek/vegytanszotar (letöltés dátuma: 2020. július 7 .)

[43] Budapesti Hírlap. 1854. március 25. 2122.

[44] Pesth-Ofner Localblatt. 8. Februar 1856. [4].

[45] Budapesti Hírlap. Hivatalos Értesítő. 1855. június 11. 4105.

[46] Ungarische Kriegsakademie. Das Vaterland. 2. Mai 1869. 2.

[47] A Hon. 1871. május 24. [3.]

\section{Gabriella Pogány Rózsa PhD}

\section{The Military Hospital \\ (Pest/Budapest) in the building of the Ludoviceum Military Academy}

The Honvédkórház (Military Hospital Pest/Budapest) moved from the Invalids' Palace to the Ludoviceum and operated there till 1871. The building in the Orczy-park was built as the Hungarian military school, but it could be opened only after the Great Compromise and the organisation of the Hungarian Royal Army. This publication presents the history of the military hospital based on the documents of the Hungarian Military Archive and contemporary newspapers and medical topographies.

Key-words: History of the military health care, Military Hospital (Pest/Budapest) 19th century 